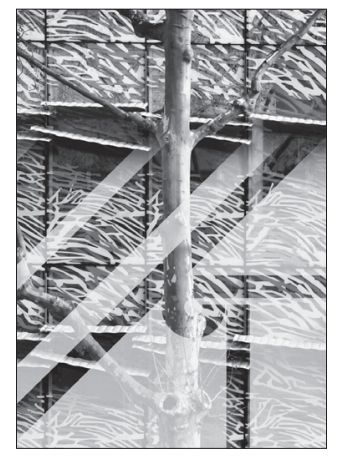

\title{
Agnieszka Kurkowska*
}

\section{Architecture in the field of art on the example of author's realizations}

\section{Introduction}

An architect participates in creation of houses, that is objects of habitation. By contributing to this inclusive process, she/he may undertake activities in the scope of architectural design, as well as artistic initiatives that refer to the field of art. The issue of habitation and determining proper facilities for this purpose may provide the subject for a message addressed to current or prospective inhabitants in the form of graphics, painting, sculpture, artistic intentional projects. The concepts contained in habitation objects result from reflections on space and improvement in its use conditions, as well as the enhancement of aesthetic values, so that buildings can exert an impact on a sense of good living (understood here as multidimensional rooting in a specific place and in a widely understood everyday life space, taking its realization in a physical and metaphysical context). This form of consideration prompted me to make an attempt at finding the answer to the question whether it is possible to situate architecture in the space of art. Projects implemented while searching for answers to the above question result from research and observation, but also mark the creative process of expressing certain content through artistic activities. The research thesis formulated in the present article is to postulate that architecture, using artistic material as a means of expression, influences the process of living by showing the recipient, i.e., the resident, values that are important from the point of view of creating a house to ensure good quality of life, with understanding various aspects of living and house structure. In the article, situations are described in which architecture offers an

* ORCID: 0000-0002-1380-4628. Faculty of Architecture, Gdańsk University of Technology, e-mail: agnieszka.kurkowska@pg.edu.pl element of research activities, not only being the result of authors' intentional designs as part of creative processes, but also resulting from research work. The effects yielded by such projects (recipient's interest, presentation comprehensibility) are presented in the article to confirm the above thesis.

\section{Methods and state of research}

The elements of the presented intentional projects were created in 2015-2020 in Gdańsk Pomerania, specifically in Kashubia, and were implemented/made public in Gdańsk. All of them relate to the issue of habitation, but use various means of expression and accompany diverse public events. They feature a similar artistic form of conveying the content related to architectural issues. This topic is presented in the research by Gabriela Świtek [1], [2] as well as the publication that followed the scientific conference on a multifaceted discussion concerning the issue of how the sculpture meets various physical and cognitive matters and contexts [3]. Many other authors also have dealt with issues related to the topic. So far, the problem of communication between the creator and the recipient has been analyzed by such researchers as Umberto Eco [4], Martin Heidegger [5], Krzysztof Lenartowicz [6] and Yi-Fu Tuan [7]. Roman Ingarden [8] and Jeremi Królikowski [9] studied and described specific relations between art and architecture, as did Gabriela Świtek [10], while Jolanta Brach-Czaina [11] referred to the ethos of new art. Juliusz Źórawski [12] and - more recently - Aleksander Asanowicz [13] analyzed the construction of an architectural form, Augustyn Bańka [14], in turn, studied the sociological and psychological aspects of creative activities within architecture. The latter research shed new light on my perception of these processes, by revealing an unobvious impact layer and specifying its scope. 
The intentional projects presented here contain original objects (graphics, paintings, sculptures, spatial installations and objects transferred directly from the real world), as such forms are based on experimenting with space, as well as they accept the challenge of creating a message within the space of ideas by going beyond physicality during the happening. Quoting Brach-Czaina [11, p. 199], it should be reminded that contemporary art seeks material in everything that surrounds humans, both surroundings and all the objects that fill the space provide subject matter. I would also include ideas in this definition.

In the light of my assumption, an ideological concept, idea or a specific message can mediate through activities bordering on architecture and art. A certain arbitrariness and symbolism refer architecture to the field of art. Also an intimate scale of operation, inconsistent with the actual dimensions of buildings is related to art. By their nature, artistic activities are characterized by synthesis, often apply elusiveness and vagueness. The objects presented below were constructed in a similar way. It must be remembered that - as Królikowski rightly noted - [...] architecture is art when it is a work of art, not a product [Author's own transl.] [9, p. 79]. Hence, an individual creative element is vital, as well as the uniqueness that relates to objects on the border of these two domains, when one advantages from the other, while both are strengthened by their coexistence.

In the activities described below (three projects selected as representations of various artistic and design activities carried out in 2015-2020), I applied a combination of research and creative methods. My paper borders on science and art. Creative work was a major contribution to the article, as art was either a tool in the process of architectural design at its initial stage, or constituted a comment or an introduction to particular design stages. The designs reveal the effect. While creating them, the methods of analysis and synthesis was applied, as was comparative research. The projects made it possible to obtain unique research material, also in the field of sociological research, which was based on documentation of events and collecting feedback from participants. I am still in the process of collecting and developing this data, due to the need to obtain a broader perspective in time. The projects themselves implement, to a varying degree, several tasks assigned to them, such as provoking reflection (especially the first one), strengthening knowledge (especially the second one), enabling the observation of direct events and analyzing their wider context (the third one). Art, in space of which I chose to placed the aforementioned projects equally strongly related to architecture, provides a tool in the design process. It is an autonomous stage of this process. Art provides a story about ideas, relationships, places and historical events. It shows an alternative point of view. Here, specifically, the point of view is one of an architect who cares for the quality and values of the surrounding space. Moreover, art offers a tool for evoking reflection and sensations experienced directly during the events to which the projects were assigned. These experiences were subject to observation, analysis, could provide an inspiration and a source of motivation to act. This understanding was at the heart of my assumptions.

\section{The role of architecture within art space}

Architecture not only concerns shaping usable spatial objects to meet various human needs, the most important of which seems to be the provision of proper shelter. It should rather be understood as a discipline that deals with education in the field of spatial shaping, including development of positive attitudes towards cultural spatial activities. Such education leads to an understanding of complexity and importance of the process of creating architectural objects and urban layouts, their personal and social implications for users. From the point of view of the above-defined thesis, house and its location in the region present issues of greatest importance to me. It is the task of the house to not only to provide with basic existential needs, but also to create the right mood, ensure a sense of belonging and identification with the object and its location.

Apart from practicing as a designer, an architect is also able to actively participate in conveying positive content, as well as securing the proper course of culture-making and pro-social processes. It should be emphasized that properly formed architecture is one [...] that, through its elements, develops cognitive processes, moderates emotional processes and triggers behavioral processes characteristic, for example, of the loyalty syndrome: towards oneself, others and the place of residence, work, rest, study or prayer (agoral behavior) [Author's own transl.] [14, p. 48]. Architecture understood in this way contributes to enhancing positive processes in the human mind. Therefore, with their actions, architects can support renewal processes with regard to neglected spaces, they can strengthen motivation towards introducing changes, as well as contribute to a better understanding of both the architectural structure of specific objects and their historical context. Consequently, an architect participates in enriching the knowledge of recipients.

It seems, therefore, that architects should avoid designing buildings only to meet utility requirements that correspond to the established functional program. Nor should buildings serve only to fit into the current aesthetic trends, as this would obscure the mission of conveying content in the form of a specific key concept, i.e. delivering the desired values (more in: [15]).

Co-creation of a sense of freedom and identity offers an important message for architecture (understood in the present paper as culturally created physical matter that participates in the process of living). In co-creating the structure of the living environment, architecture should respond to specific assumptions so as to take into account the needs of prospective residents in the case of important issues related to the structure and equipment of a house. Since residents' involvement is a fairly common practice nowadays, their great autonomy and resourcefulness in this matter should be regarded with optimism. Grażyna Woroniecka stated that: The material and cultural modules from which we build our living experience are characterized by increasing diversity. The stronger the pressure for behavior uniformity on city dwellers in the public space, the greater the venting to their individuality in their own apartments [Author's own transl.] [16, p. 27]. 
Woroniecka noticed another important aspect, i.e., an objective need to individualize one's own home, individualization that determines its distinctiveness, contractual separateness, or recognition. Hence, the residents can derive a sense of self-determination, which is also based on separating themselves as an individual from a group connected by the implementation of common goals. Co-creation of a group leads to a formal unification of the space inhabited by this group, while maintaining the aforementioned separateness. The inner need for individualization applies particularly to living space [17]), because it is at home where our distinguishability may co-create the feeling of "being at home".

It should be remembered that $[. .$.$] the collective pro-$ cess of creating the "I" identity consists, among other aspects, in presenting oneself to others, forcing conformism and resolving conflicts related to the existence of various perceptions of order in the minds of the family community members [Author's own transl.] [18, pp. 47, 48]. If the issue of identity is understood in this manner, the aforementioned sense of freedom should be seen as beneficial (as it refers to moving within the space of intellectual freedom that allows a choice of behavior). The creation of a space of ideas, as an extra-physical area whose task is to enable the visualization of one's own ideas, which in turn strengthens the feeling of independence, should also be perceived as conducive to the creation of identity. However, the basis of architectural activities should be sought in understanding the purpose of action and existence, as well as the logic behind this process which is carried out by humans in their living space (cf. [14, p. 48]). Such a genesis of actions would foster creativity towards freedom of actions and thinking ${ }^{1}$.

From the point of view of the issue analyzed in the present paper, the moment when architecture entered galleries and museum spaces in the 1970s is of great importance. As pointed out by Świtek, it is the official entry of architecture into the world of art previously reserved for strictly abstract activities that should be considered conducive to expanding its field of influence [10, pp. 222, 223]. Thus, architecture changes its dimensions. Attention is drawn to concepts, content, and the moods created. The revealed relationships assume a new dimension. Multidimensional reflection and various levels of experience are allowed. Hence, such an approach to architecture offers a new experience that allows for a deeper understanding, but also for expressing the essence of the role of architecture. Exhibition spaces, being special places for presenting cultural objects, somewhat give credence to architecture as a medium of conveying content, including ideas, as a subject of inspiration ${ }^{2}$. Therefore, spatial objects, though previously regarded as the ones that strictly belong to the field of architecture, namely an inextricable conglomerate of engineering and the architect's creative element, can now be considered (according to their metaphysical layer)

\footnotetext{
1 Similar observations in the work [19].

2 The modern, almost unquestionable belief that architecture is art results from such aspects as the presence of architecture at art exhibitions $[17$, pp. 222, 223].
}

as equal to other artistic objects assigned to the area of art, with common consent for their presentation in exhibition spaces today ${ }^{3}$ (quoted after: [10, p. 424]).

\section{Ideological architectural sculpture}

The work of an architect is located in between functional design and art. Architect's actions are simultaneously distinguished by aspects of both usefulness and ideology. In their actions, architects who strive after creating architectural objects, introduce changes in space, shape the landscape or urban layouts. They can support themselves not only with a sketch and a picture or text, but also a special medium - an ideological architectural sculpture. By this I understand a special type of model, which is both a sculpture and a model layout that has the appearance of an architectural object. It is a kind of artistic matter that allows for the transmission of ideas, moods and non-verbal content that must be supported by a conceptual object. This particular form of expression can be referred to as an ideological architectural sculpture. It emerges as a result of a sculptural creation, but also constitutes an important element of the architectural design process (more in: [20]). In order to understand what specific place architecture can occupy within the scope of this process, it would be useful to distinguish the boundaries that separate subsequent stages of such a design (cf. [6, p. 65]). The aforementioned process is commenced at a time of initial reflection, followed by geometrization of the notes (more in: [21, p. 236]). Another distinction concerns the stage of linear record and the subsequent spatial formation (although the transition may be smooth). Then, the modeling activity can be distinguished, which also provides the final stage of spatial formation. It is then that an independent sculptural object can be created (which constitutes an autonomous completion of the work or a starting point for creating the final architectural object). Another distinction marks the stage of transition from the concept phase to the design of an architectural object. The final stage comprises implementation of the object (cf. [20]).

Thanks to its scale, a model of small cubature that an ideological architectural sculpture usually consists of may enable a synthetic perception ${ }^{4}$ of architecture. When reception of a physically implemented architectural object means covering a certain path, undergoing a specific route, within a certain time, which affects the dynamics of architecture perception, in the case of a sculpture, what occurs is a reduction of this path (thus shortening the perception time). This probably impoverishes the aspect of a multi-sensational comprehensive reception ${ }^{5}$. However, it can be expected that precisely due to the simplification of the form and the specific condensation of reception

\footnotetext{
3 Compare: the international exhibition "Design and Art", Department of Modern Art of the National Museum in Gdańsk (May-August 2015).

4 In terms of the time spent and the distance traveled, due to the size of the object and the fact that it is isolated from the context.

5 A real architectural object speaks with its form, detail, sound, light, smell and vibration.
} 
process, the recipient's attention focuses on the essence of the issue, i.e. on the content of the message.

Perhaps the simplification related to the aforementioned ideological architectural sculpture may contribute to the enhancement of its legibility. The experience is not accompanied by distraction, which seems inevitable in the situation of large objects' reception (much longer in time). Additionally, the latter case, due to its conditions, cannot be experienced in isolated situations. Aleksander Asanowicz noticed that [...] during a single act of perception, a person perceives very little. Space is perceived most intensively when its elements are only "sketched" and not fully completed [Author's own transl.] [13, p. 16]. An ideological architectural sculpture is exactly such a physicalized sketch, a realized concept. As such, it has a structure, shape, it is traced, refers to patterns, relations and symbols. It coexists with its cultural context. While analyzing the aspect of the psychophysiology of sight, Iwona Mikołajczyk noted that [...] the viewer rarely perceives the entire perceptual field due to the fact that the most intense stimuli, corresponding to needs and emotional states (affordance) are the first to reach the observer. Often its reception is directed by habits, which introduce mechanical reactions into the perception process, resulting in fixations or hypercoding [Author's own transl.] [22, pp. 9, 10].

A small-scale model could therefore lead to sensations and experiences in a manner comparable to those obtained for a full-sized object. This results from the inclusion of the recipient's experiences in the perception process. The perception is still different, no departure occurs, no accompanying elements, experienced relationships are inadequate to the real ones 6 .

However, in the process of perception, the human mind overcomes these inconveniences and enables the recipient to correctly read the content.

I use ideological architectural sculptures in the three intentional projects described below. The common feature of the projects lies also in the transfer of architectural concepts in the space of art. Namely, by using artistic objects and taking advantage of public exhibition events. In all projects, art provides a form of communication in general architectural education, which leads to the enrichment of experiences and broadening knowledge, as well as sensitization to the topics discussed.

\section{The author's own intentional projects}

\section{“Unierzeczywistnienie” Spatial structure}

An ideological idea, concept, and a specific message can mediate through actions that border on architecture and art. Certain conventionality and symbolism refer concepts to architecture and art alike, as does scale of action, inconsistent with the actual dimensions of the buildings. Art is

${ }^{6}$ Contrary to appearances, a three-dimensional model is not a better way of recreating reality than a drawing in order to obtain perceptual impressions as close as possible to those perceived in real space. This is because we usually deal with models on a reduced scale, which are viewed from a tainted perspective [Author's own transl.] [18, p. 77]. a synthesis that often applies elusiveness and vagueness. Motivated by a specific intention to act, an architect enters this space with the intention to convey a message appealing to the senses, to enrich experiences and knowledge.

The spatial structure entitled "Unierzeczywistnienie" [Unrealization] (Fig. 1) may be seen as an example of an intentional action. The structure actually emerged as part of the open-air art festival "Obrazy Ogniem Malowane" [Pictures Painted with Fire] organized by Gdański Archipelag Kultury "Plama" [Gdańsk Archipelago of Culture "Plama"] in October of 2015. The subject of the project are ideological architectural sculptures placed in the public space of a housing estate of multi-family buildings, located in the Gdańsk district of Zaspa; colloquially known as blokowisko [block of flats estate], which presents the connotations caused by living in this space. Prefabricated, ten-storey, objects with multiple staircases, built in the 1970s, constitute the formal context of the event. Mainly local residents are the recipients of the project.

The architectural spatial structure is based on the uniqueness of a spatial situation. The attitude of intentionality adopted by me to accompany the participants of the event, assumed the activity of the recipient's mind in re-

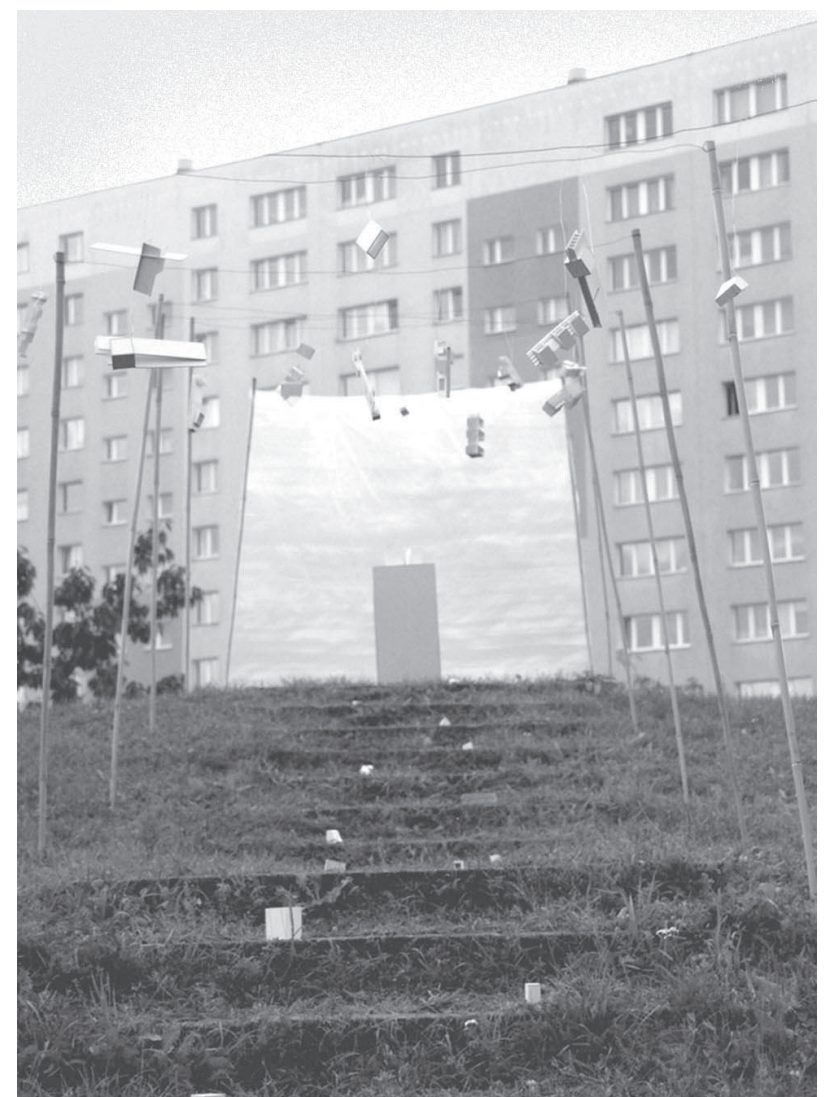

Fig. 1. Intentional project entitled "Unrealization", Outdoor Festival "Pictures Painted with Fire", Gdański Archipelag Kultury

[Gdańsk Archipelago of Culture], Gdańsk-Zaspa, October 2015 (author: A. Kurkowska, photo by A. Kurkowska)

Il. 1. Projekt intencjonalny pt. „Unierzeczywistnienie”, Festiwal Plenerowy „Obrazy Ogniem Malowane”,

Gdański Archipelag Kultury, Gdańsk-Zaspa, październik 2015 (autor: A. Kurkowska, fot. A. Kurkowska) 


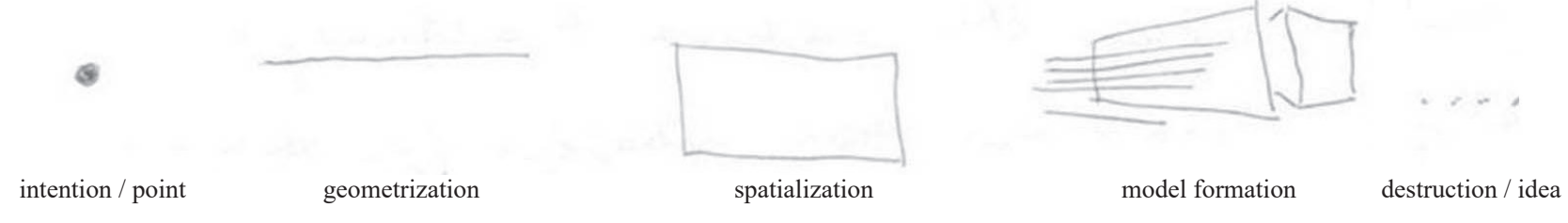

Fig. 2. Ideogram of a disturbed design process in connection with the implementation of the installation "Unrealization" (elaborated by A. Kurkowska)

Il. 2. Ideogram zaburzonego procesu projektowania w związku z realizacją instalacji „Unierzeczywistnienie” (oprac. A. Kurkowska)

lation to the subject, in accordance with its understanding in line with the trend of phenomenological philosophy. In principle, intentionality was to precede and at the same time dominate the implemented form, both in relation to individual objects and the overall space layout. The initial concept was to "ask" questions, and then "listen" to the answers, revealed through the attitude of the recipients who deliberately or accidentally participated in this situation.

While the gesture of creation realizes the content (Fig. 1), externalizes it within the model, and then in the architectural object, the gesture of destruction, here: burning, takes the form of a realized concept, dematerializing it and releasing the concept (Fig. 2).

The unrealization of an object refers to its physical form. One of the educational aspects of the described situation lies in the disclosure of architecture in its non-obvious version of the "ideological architectural sculpture". It appears, as mentioned before, on the border between the space of art and architecture, as well as the activities dedicated to and accompanying the two disciplines. In addition, the planned destruction should result in the awareness of the difficulty to implement all ideas in mind in the material of the architectural objects being created.

Many fragments of the content of the author's message remain trapped in "shelved" concepts, where they tend to remain forever. It is advisable to release these thoughts and let them return to the non-material space of ideas, from where they may try to attach to realistic objects again.

According to the project assumptions, the educational aspect was to be completed through reflections, experiences, experiences and the possibility of participation. Experiences were to be shared in this particular context of the undervalued space of a block of flats estate. Therefore, the intention was also to reveal my personal reflection on the subject of experiencing identification with a particular place of residence, namely a housing estate in the Gdańsk district of Zaspa. Additionally, in the described situation, the educational space overlapped the meeting space, thus becoming a "reception situation" for both parties involved in the experience (cf. [19]).

\section{"Nie-pokój wizytujących nieznajomych"}

The second project I will present here is an intentional project of my co-authorship entitled "Nie-pokój wizytujących nieznajomych" [Non-room for visiting strangers] $]^{7}$.

7 The project was submitted to the competition accompanying the sixth edition of the International Festival "Narratives" in the Gdańsk dis-
It was based on the concept to create a meeting space and, indirectly, non-literally, a living space. This space was created by evoking memories and imagination of its former appearance and by the temporary residence of "visiting strangers" in this space. As understood by Marc Augé, "non-places" may mean [23, p. 54], transit spaces or places intended for temporary stay, which is often identical. According to the understanding of the authors of this installation, "non-places" exist with no superior goals, they are defined by indeterminacy. This, paradoxically, provides a guarantee of freedom to their users. Therefore, no specific rules or guidelines prevail. Elusive ties and bonds that are hard to define are formed with the environment. By design, non-places avoid unambiguity, tend to be seemingly unattractive, as they resemble phenomena apparently similar in any urban space. Hence, by analogy, the authors" concept of "non-room".

The authors' intention was to invite recipients to a unique journey in time and space. "Not-room" and yet a room; additional, temporary, but extremely personal. Existing alongside someone else's identity: identifiable, and yet not identical. Ideally, the concept is based on the transposition of an unreal vision into the real world; a vision is enriched with realities of the past of smuggling in this place: smuggling words, values. Asking questions about the meaning of non-physical interpersonal relationships and the awareness of other people's existence motivate us, offer us support, hope, and fill us with the fear of ignorance, which when overcome, usually results in a wealth of new experiences. Exposing the recipient to painterly-sketched references to reality and thoughts, experiences and guesses, fears and longings puts him/her in a situation of a need for a new experience, the necessity of an act of additional reflection (cf. [19]).

For the duration of the "Narratives" festival, in an "outhouse" facility (currently a drying room) in an existing "non-place", according to the author's concept, a space for temporary residence was to be created: "non-room for visiting strangers" (Fig. 3). Everyday fabrics would be replaced by banners with images of "strangers". According to Kazimierz Jałowczyk, the author of the images, the nature of these visualizations would be strictly unintentional, objective - open, which means allowing various interpretations, thus placing their meaning in the category of an open problem.

trict of Nowy Port, under the name "Smugglers". Co-author: dr inż. arch. Małgorzata Kaus, author of images and ideas of "strangers" called up for temporary residence: dr hab. Kazimierz Jałowczyk. 


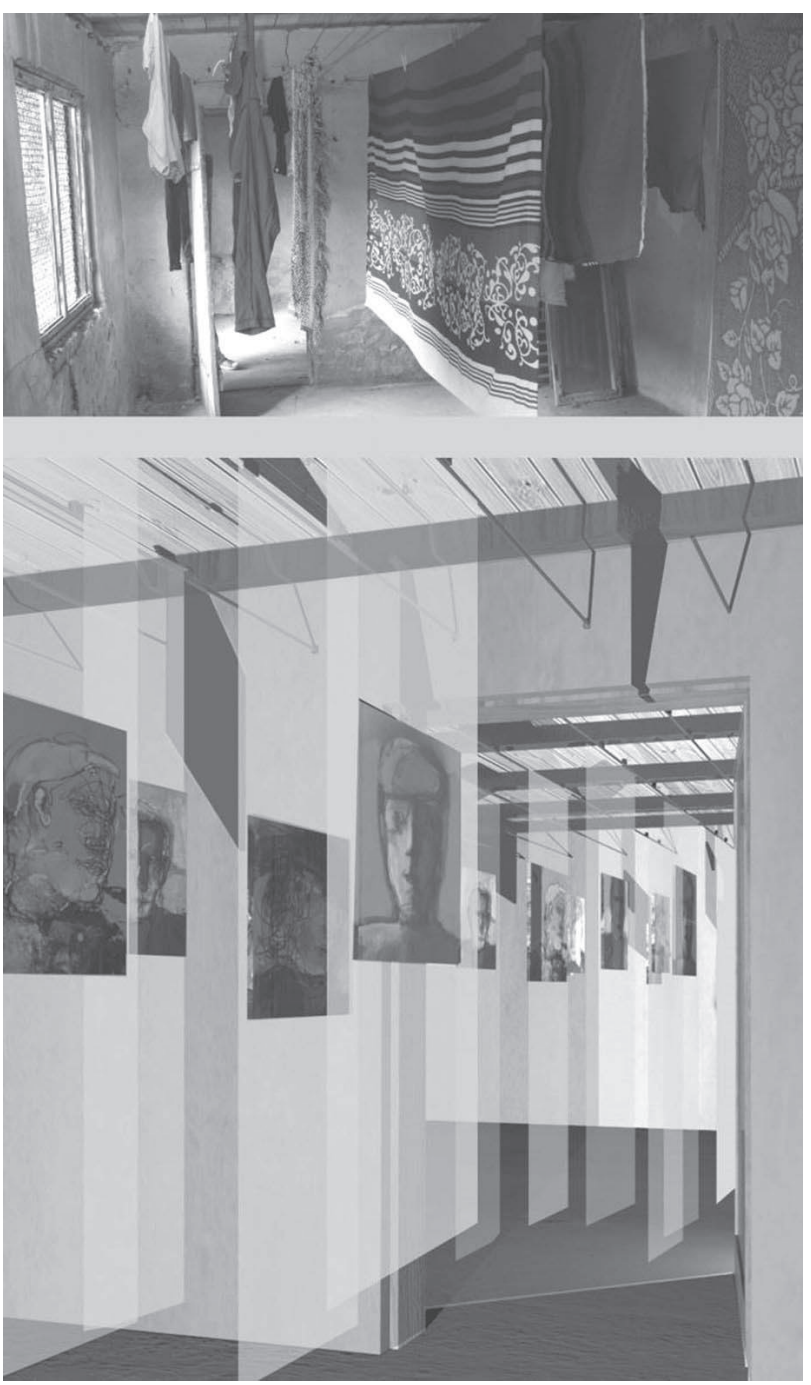

Fig. 3. The existing drying room in Nowy Port and the concept of an intentional spatial structure project entitled "Niepokój wizytujących nieznajomych", Gdańsk-Nowy Port 2015

(design: A. Kurkowska, M. Kaus, photo and visualization by M. Kaus)

Il. 3. Istniejąca suszarnia w Nowym Porcie i koncepcja projektu intencjonalnej struktury przestrzennej pt. „Nie-pokój wizytujących nieznajomych”, Gdańsk-Nowy Port 2015 (autor: A. Kurkowska, M. Kaus, fot. i wizualizacja: M. Kaus)

The slogan "smugglers" can provide a useful semantic clue here. Smugglers may be seen as not only risk-takers who deal with contraband. In oppressive times, smuggling was also marked with a noble and creative character. Smugglers who engaged themselves in illegal acquisition of forbidden literature, cultural goods, and technical means could be found. It was a job that required exceptional courage. This fact is worth remembering when lacking courage to fight for the expression of one's own identity, to make the place of living more accessible and tailored to individual needs and expectations, so that it can become a real Home, rather than just a place for human existence devoid of a feeling of rootedness and identification that should strengthen such a place.

The project is aimed to recall memories, mark history, meet people who are temporarily absent, and visualize du- rability and continuity of past events (perhaps too easily consigned to oblivion).

Józef Przybylski, an opposition activist, writer, and a resident who inhabited a nearby tenement house in his childhood and adolescence, would be ideologically invited to this space. Formerly, an everyday visitor to this yard, an opposition smuggler under the communist regime. Now, for the participants of this spatial situation, he would be packing in cans (like he did years ago with "subversive" publications in the factory, abroad) copies of imaginary visiting smugglers, smuggled strangers, created with the use of the artist-painter's (Kazimierz Jałowczyk's) talent and imagination. Przybylski's sister returned to the area after many years in order to pass on her feelings and experiences to her grandchildren at her childhood playground. She currently lives in a tenement house adjacent to the laundry room chosen for the presentation. The washed clothes that she is hanging, which sometimes mean and resemble something, at the same time not meaning or recalling anything important, would be temporarily replaced by symbolic figures. Imaginary, expressively drawn parahuman creations force the recipient to confrontation. In this way, a transgressive exposure of images of strangers emerges.

\section{“Kaszubskie zamieszkiwanie. Studium”}

In the project entitled "Kaszubskie zamieszkiwanie. Studium" [Kashubian inhabitation. A Study] art offers a medium for testing architectural concepts. It allows to verify the relationship, potential and feelings related to the topic: living in Kashubia. Kashubia is a northern region of Poland (from the coast to the southern borders of the Kashubian Lake District), marked with special natural and cultural values (cf. [24, pp. 60, 62]). Such values cannot be ignored in the process of architectural design in this location. Studies on regional building development and the accompanying geographic and botanical context have evolved into a cyclical activity in artistic subject matter. Such thoughts have been expressed in the form of graphics, painting and photographic representations of the living space through painting and sculpture. These representations externalize the search for new means of expression with which to display personal reflections on the home and its environmental relations. Thus, they complement research and design work, as they consists of a collection of many artifacts created in the years 2016-2020.

The "Kaszubskie zamieszkiwanie. Studium" series result from a scholarship project implemented in $2020^{8}$. The collection of graphics, paintings, sculptures and photographs was presented in November of 2020 in the form of an exhibition at the headquarters of Gdański Archipelag Kultury 9 .

8 Scholarship of the Marshal of the Pomeranian Voivodeship for creators of culture for 2020 .

9 The exhibition entitled "Kashubian inhabitation. A study", curator: Dr. Paulina Kminikowska, PLAMA Gdański Archipelag Kultury, Gdańsk-Zaspa. 
Fig. 4. Selected paintings and sculptures, exhibition "Kaszubskie zamieszkiwanie. Studium", PLAMA Gdański Archipelag Kultury, Gdańsk-Zaspa (author: A. Kurkowska, photo by A. Kurkowska)

Il. 4. Wybrane obrazy i rzeźby na wystawie pt. "Kaszubskie zamieszkiwanie. Studium", PLAMA Gdański Archipelag Kultury, Gdańsk-Zaspa (autor: A. Kurkowska, fot. A. Kurkowska)

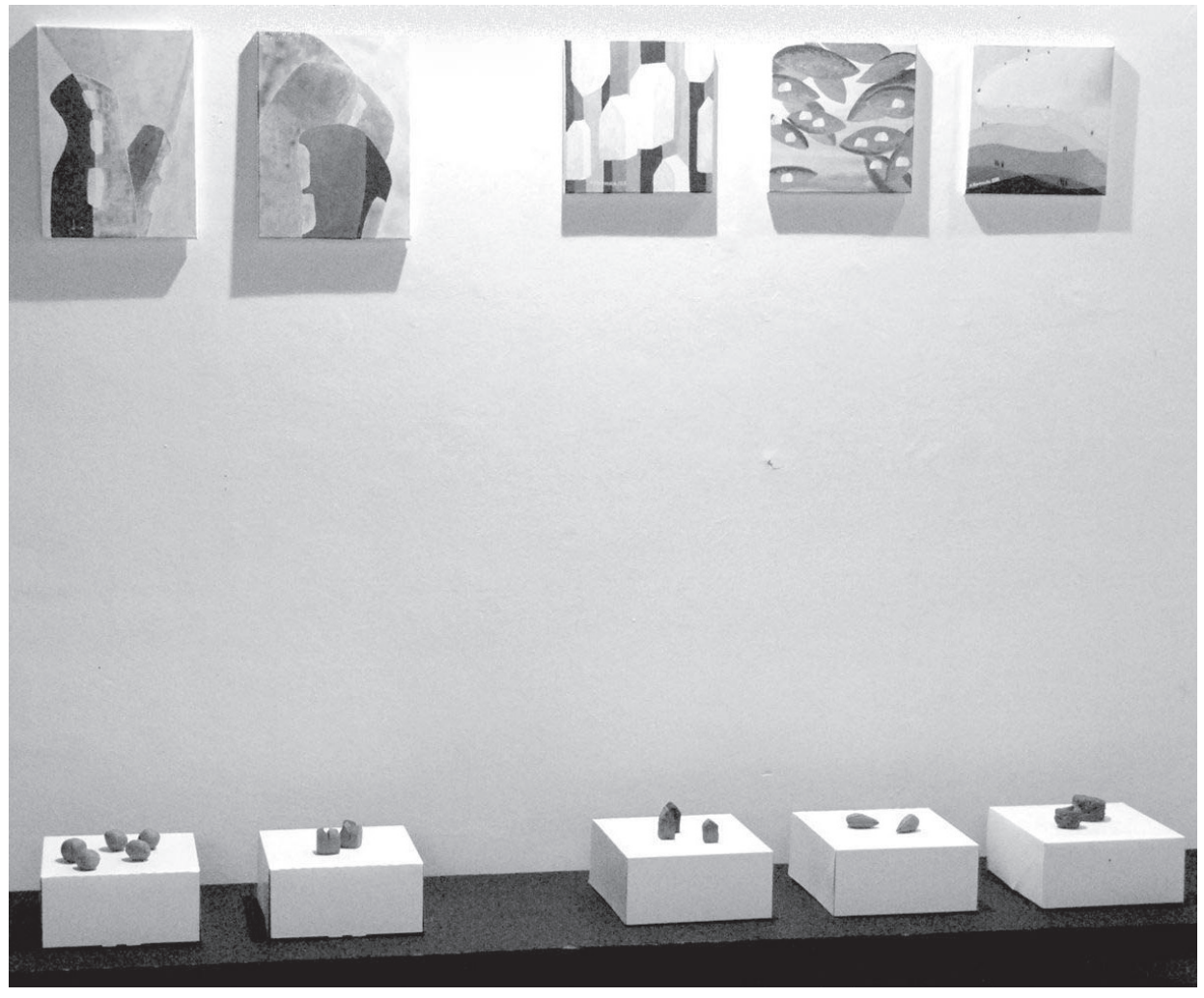

The study reveals thoughts, observations and images of a house embedded in the region - growing out of local conditions (Fig. 4, 5).

The architectural object keeps growing. It consists of successive stages of natural development of the living process in terms of design and implementation, and then the use of an architectural object. The ideological architectural sculptures implemented in accordance with their ideological concept and the graphics preceding the models, reveal several aspects of the issue.
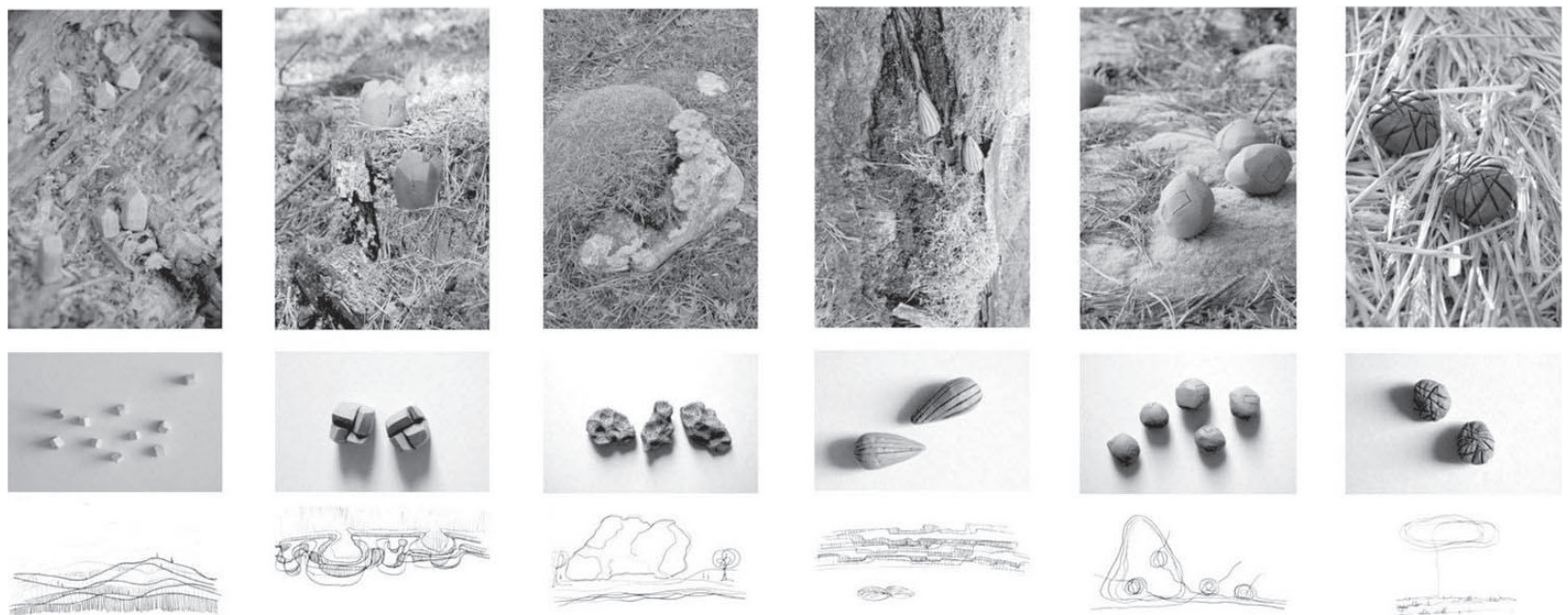

Fig. 5. Selected sketches and photos from the placement of sculptures in the Kashubian natural realities, exhibition entitled "Kaszubskie zamieszkiwanie. Studium” Gdański Archipelag Kultury PLAMA, Gdańsk-Zaspa (author: A. Kurkowska, photo by A. Kurkowska)

Il. 5. Wybrane szkice i fotografie z lokowania rzeźb w kaszubskich realiach przyrodniczych, wystawa pt. „Kaszubskie zamieszkiwanie. Studium”, PLAMA Gdański Archipelag Kultury, Gdańsk-Zaspa (autor: A. Kurkowska, fot. A. Kurkowska) 
Its form, originally determined by its function, ensured safety and symbolically informed the inhabitants about it. By visually blending in man-made objects with their natural surroundings, a sign of residence is created, which illustrates the place of belonging and allows to store important traces and signs in memory as an imaginary representation of the place of origin and existence (Fig. 5).

Considering what a house is or should be like leads not only to engineering issues, but, above all, to philosophical reflections or sociological analyses. By inhabiting a space, a human being secures the essential need for shelter and realizes various accompanying needs, such as the needs that point architectural activities towards extra-physical spaces. Such issues, in turn, tend to border on art rather than technology. And so again, architecture finds freedom of expression in the space of art, in line with my conviction that the path I have chosen is the right one.

\section{Conclusions}

As noted by Gabriela Świtek, by reaching for models and mock-ups, artists use them as records of a specific concept of space, while architects use this form of representation as a record of philosophical considerations, both on the sources and functions of architecture. A model or spatial structure treated in this way may prove an intuitive record of an idea, a formally distant prototype of the target form. The next stages of implementation only force us to confront the technological and design possibilities of the target building material (as cited in: [10, p. 426]).

The projects presented above support the phenomenon of "necessary rooting" named so by Ewa Rewers (with regard to embedding actions in contexts of meaning) [25, p. 9]. Without such rooting, possible semantic interpretation of reality becomes marginalized, superseded by new, both colloquial and research strategies, and thus it becomes a common element of the contemporary life infrastructure. Rooting allows for a broad understanding of cultural space, extends its meaning to the entire city, but also points to elements important to culture. It reveals authentic actions and objects, at the same time co-creating the space of culture in terms of meaning: [rooting] concerns elements which can belare used, with greater and greater success, as elements of cultural identities. This approach assumes a way of thinking in which culture is recognized not as a closed area, and therefore does not yield ready-made answers and solutions [Author's own transl.] [25, p. 9].

In the light of the above considerations, do the above examples help to situate architecture in the space of art? Do they communicate not through words, but through, as Ewa Borowiecka states, "richly endowed things" [26, p. 86], which is a specific sign of art? Does intentionality, which lies at the basis of these three presented activities and other ones implemented by me, and not mentioned in the text ${ }^{10}$, entitle these objects to be in-

10 Another example is the object called "House as a sign of identity", A. Kurkowska [in the framework of:] The International Design and scribed in the area of art space? "Art (which places itself) [in:] space?"11

It seems that intentions and implementations simultaneously belong to art and architecture, on which they border. Due to the authorship by an architect who works on such projects with all the baggage of professional experience, their architectural affiliation seems obvious. However, once released from the rigors of utility form and the necessity to meet functional and technological requirements, architecture is allowed to present the ideological sphere, as legible as in the case of related means of expression, i.e., purely artistic intentions. The content is realized in the form of an intentional concept, specified within an object free from the utility function of an architectural object, i.e., in an ideological architectural sculpture. Owing to the above, the key concept becomes more readable, and its message stronger. This is where a special mission of architecture lies, namely architecture created in the space of art.

Due to the created projects and the actual implementation of two of them, I was able to realize the postulates of my earlier research work on living space (see [19]). The application nature of the work made it possible to verify the potential of the tools applied and to obtain partial feedback on the scope of their readability. An attempt was made to achieve the goals formulated in the cited work as conclusions from research analyses. In addition, the third project itself may be seen as an element of more extensive research into space and architectural forms that fit with it.

The projects presented in the article were accompanied by questionnaires, but the conducted research did not provide fully satisfactory results, perhaps due to the outdoor nature of the event (the first project) and the difficult pandemic situation (the third project). The second project, being a study project, could not be covered by the survey. Differently prepared questionnaires seem to provide useful research material for the future, provided that greater numbers of recipients of the projects fill them in. I intend to continue projects of a similar nature and present them in public spaces, while examining their legibility.

To sum up, one may be tempted to conclude that it is worth remembering the fact that architecture, while it uses an artistic object as a means of expression, may affect the process of living by directing the recipient-resident to important values from the point of view of creating a home that ensures a good life quality and by strengthening their understanding of both, the living aspects and the structure of the house. Art, within which architecture is located in the above-mentioned projects, provides here (in various forms and to a different degree) a tool for communication, self-reflection, research method, a means of artistic expression. The author's original proposals provide

Art Exhibition. National Museum in Gdańsk, Department of Modern Art, 2015 and [as part of:] the International Exhibition "Mosty Sztuki -Art Bridges", Kalisz 2015 University Art Gallery, Faculty of Pedagogy and Arts of the University of Adam Mickiewicz in Kalisz.

11 Transposition of the title of the international conference organized as part of the DOFA, Wrocław 2016. 
unique statements that offer insight into the subjective, hermetic world of the creator, but also open horizons to the established, multi-layered process in which each of us participates. It is true that these activities are similar in the concept of site-specific art, but they could also be treated as ones that belong to social art, due to their focus on the social context, namely the addressees, present and prospective inhabitants of the places mentioned (cf. [27]).

This is exactly the way in which architecture creates not only material, but also cultural modules from which experience is built in the complex process of living. The need to mark one's own outlook and to provoke its emergence in recipients becomes a response to the strong pressure to standardize the behavior of city dwellers in public space. Hopefully, this need for individualization translates into the need to shape individual houses, even if these are flats within multi-family housing estates, seemingly doomed to failure in relation to the possibility of experiencing identification in living (cf. [19, p. 27]).

Translated by Emilia Metgieś

\section{References}

[1] Świtek G., Aporie architektury, Zachęta Narodowa Galeria Sztuki, Warszawa 2012.

[2] Świtek G., Niesamowicie, czyli o efektach architektury, „Autoportret. Pismo o Dobrej Przestrzeni” 2014, nr 4(47), 10-15.

[3] Paragone. Rzeźba na granicy, E. Błotnicka-Mazur, L. Lameński, M. Pastwa (red.), Stowarzyszenie Historyków Sztuki, Wydawnictwo KUL, Lublin 2016.

[4] Eco U., Nieobecna struktura, Wydawnictwo KR, Warszawa 1996.

[5] Heidegger M., Budować, mieszkać, myśleć. Eseje wybrane, Czytelnik, Warszawa 1977.

[6] Lenartowicz K., O psychologii architektury. Próba inwentaryzacji badań, zakres przedmiotowy $i$ wplyw na architekturę, Monografia nr 138, Wydawnictwo Politechniki Krakowskiej, Kraków 1992.

[7] Tuan Y., Przestrzeń i miejsce, Państwowy Instytut Wydawniczy, Warszawa 1987.

[8] Ingarden R., O dziele architektury, [in:] R. Ingarden, Studia z estetyki, t. 2, PWN, Warszawa 1958.

[9] Królikowski J.T., Sztuka architektury - architektura sztuki. Dzieło - fenomen - przestrzeń - obraz świata, "Czasopismo Techniczne. Architektura" 2004, R. 101, z. 10-A, 79-83.

[10] Świtek G., Gry sztuki z architektura. Nowoczesne powinowactwa i wspótczesne integracje, Wydawnictwo Naukowe UMK, Torun 2013.

[11] Brach-Czaina J., Etos nowej sztuki, PWN, Warszawa 1984.

[12] Żórawski J., O budowie formy architektonicznej, Arkady, Warszawa 1973.

[13] Asanowicz A., Percepcja jako czynnik ksztaltujacy forme architektoniczna, Wydawnictwa Politechniki Białostockiej, Białystok 1998.

[14] Bańka A., Architektura psychologicznej przestrzeni życia. Behawioralne podstawy projektowania, Gemini-Print, Poznań 1997.

[15] Kurkowska A., Tożsamość a miejsce zamieszkiwania, [in:] L. Sikorska, J. Jarząb, M. Frątczak (red.), (Non)Belonging: (Re)Reading Identities / (Nie)przynależność: (re)definicja tożsamości, t. 2, Wydział Anglistyki UAM, Poznań 2016, 33-48.

[16] Woroniecka G., Wstep. Co znaczy mieszkać, [in:] G. Woroniecka (red.), Co znaczy mieszkać. Szkice antropologiczne, Wydawnictwo TRIO, Warszawa 2007, 13-27.
[17] Kurkowska A., Istota indywidualnego projektowania domów, [in:] B. Komar, J. Biedrońska, A. Szewczenko (red.), Badania interdyscyplinarne w architekturze 1, t. 1, Wydawnictwo Wydziału Architektury Politechniki Śląskiej, Gliwice 2015, 205-216.

[18] Rancew-Sikora D., Dom estetyczny jako dom indywidualny, [in:] G. Woroniecka (red.), Co znaczy mieszkać. Szkice antropologiczne, Wydawnictwo TRIO, Warszawa 2007, 47-72.

[19] Kurkowska A., Przestrzenie architektury $w$ kontekśsie zamieszkiwania, Wydawnictwo Uczelniane Politechniki Koszalińskiej, Koszalin 2017.

[20] Kurkowska A., Ideowa rzeźba architektoniczna. Dom, [in:] E. Błotnicka-Mazur, L. Lameński, M. Pastwa (red.), Paragone. Rzeźba na granicy, Stowarzyszenie Historyków Sztuki, Wydawnictwo KUL, Lublin 2016.

[21] Kurkowska A., Struktura procesu projektowania obiektu architektonicznego w ujęciu geometrycznym, [in:] T.G. Baranowskaja (red.), Topical problems of World Artistic Culture. In memory of Professor I.D. Rozenfeld, t. 1, Hrodzienski Dziarżauny Uniwiersitet, Grodno 2015.

[22] Mikołajczyk I., Gdzie wspólne jest krą̇enie rzeczy. Przyleganie sztuk pięknych i literatury. Egzemplifikacje, Wydawnictwo Uczelniane Politechniki Koszalińskiej, Koszalin 2014.

[23] Augé M., Nie-miejsca, PWN, Warszawa 2011.

[24] Studium geograficzno-przyrodnicze i ekonomiczne województwa gdańskiego, J. Moniak (red.), Gdańskie Towarzystwo Naukowe, Gdańsk 1974.

[25] Rewers E., Marginalizacja interpretacyjnej mocy kontekstu, "Autoportret. Pismo o Dobrej Przestrzeni" 2012, nr 1(36), 6-15.

[26] Borowiecka E., Poznawcza wartość sztuki, Wydawnictwo Lubelskie, Lublin 1986

[27] Niziołek K., Sztuka spoleczna. Koncepcje - dyskursy - praktyki, Wydział Historyczno-Socjologiczny Uniwersytetu w Białymstoku, Fundacja Uniwersytetu w Białymstoku Universitas Bialostocensis, Białystok 2015.

\section{Abstract}

\section{Architecture in the field of art on the example of author's realizations}

The aim of the article was to show the place of architecture in the space of art on the example of original projects. In the author's opinion, architecture, using an artistic object as a means of expression, influences the process of living by showing the recipient, who is an inhabitant, important values from the point of view of creating a house that ensures a good quality of life and strengthening the understanding of both various aspects of living and elements of the house structure. The text presents original intentional projects, being the results of research work, and presents the manner and scope of their impact on the living process.

The subject of the three described projects were spatial installations using, in two cases, ideological architectural sculptures as an artistic medium. All the projects had home and habitation as their leading themes. Their task was to recall memories, strengthen the sense of identification, or recall the values supporting the said dwelling. 
During the research, ideological architectural sculptures were placed in the natural landscape of Kashubia and in a block of flats. Appropriate photographic and descriptive documentation was made, constituting the basis for work according to the analytical and comparative method. An attempt was also made to conduct a survey of project participants and recipients.

The article not only presents original attempts, the considerations contained in it may also inspire non-obvious activities, combining science and art, indicating the applicative nature of the former and the essence of the latter

Key words: ideological architectural sculpture, art, architecture, inhabitation

\section{Streszczenie}

\section{Architektura w przestrzeni sztuki na przykladzie realizacji autorskich}

Celem artykułu było ukazanie miejsca architektury w przestrzeni sztuki na przykładzie projektów autorskich. W opinii autorki architektura, wspierając się obiektem artystycznym jako środkiem wyrazu, wpływa na proces zamieszkiwania poprzez wskazanie odbiorcy, będącemu mieszkańcem, istotnych wartości ważnych z punktu widzenia stworzenia domu zapewniającego dobrą jakość życia oraz wzmocnienie rozumienia zarówno różnorodnych aspektów zamieszkiwania, jak i elementów struktury domu. W tekście zaprezentowano autorskie projekty intencjonalne stanowiące poniekąd efekty pracy badawczej oraz zreferowano sposób i zakres ich wpływu na proces zamieszkiwania.

Przedmiotem trzech opisanych projektów były instalacje przestrzenne posiłkujące się w dwóch wypadkach ideowymi rzeźbami architektonicznymi jako medium artystycznym. Wszystkie projekty odnosiły się do domu i zamieszkiwania jako tematów przewodnich. Ich zadaniem było przywołanie wspomnień, wzmocnienie poczucia utożsamienia czy przywołanie wartości wspierających wspomniane zamieszkiwanie.

Podczas badań lokowano ideowe rzeźby architektoniczne in situ. Wykonano stosowną dokumentację fotograficzną i opisową stanowiącą podstawę do pracy według metody analitycznej i porównawczej. Podjęto też próbę przeprowadzenia ankiety wśród uczestników i odbiorców projektów.

W artykule nie tylko zaprezentowano autorskie próby i przedstawiono rolę sztuki w procesie powszechnej edukacji architektonicznej, zawarte w nim rozważania mogą bowiem stanowić też inspirację do podejmowania działań nieoczywistych, łączących naukę i sztukę, wskazując aplikacyjny charakter pierwszej i istotę drugiej.

Słowa kluczowe: ideowa rzeźba architektoniczna, sztuka, architektura, zamieszkiwanie 